\title{
Development of a Protein-Rich Ready-to-Eat Extruded Snack from a Composite Blend of Rice, Sorghum and Soybean Flour
}

\author{
Mary Omwamba*, Symon M. Mahungu \\ Department of Dairy, Food Science \& Technology, Egerton University, Egerton, Kenya \\ Email: ${ }^{*}$ marynyambeki@yahoo.com
}

Received 22 May 2014; revised 25 June 2014; accepted 8 July 2014

Copyright (C) 2014 by authors and Scientific Research Publishing Inc.

This work is licensed under the Creative Commons Attribution International License (CC BY).

http://creativecommons.org/licenses/by/4.0/

(c) (i) Open Access

\begin{abstract}
Extrusion cooking is an ideal method for the manufacture ready-to-eat snacks. The benefits include increased protein and starch digestibility in protein-enriched cereal snack products. Extrusion cooking needs to be controlled if product quality is to be maintained. Extrusion cooking was carried out at barrel temperature of $110^{\circ} \mathrm{C}-150^{\circ} \mathrm{C}$, screw speed of $350-450 \mathrm{rpm}$, and feed moisture of $12 \%-14 \%$ to investigate the effect of extrusion conditions on physical properties (expansion ratio and bulk density) of a rice, sorghum and soy flour blend. From response surface analysis, expansion ratio and bulk density were found to be significantly $(P<0.05)$ dependent on feed moisture and barrel temperature while the screw speed had a significant $(P>0.05)$ effect. Expansion ratio and bulk density ranged from 2.0 to 2.6 and 0.79 to $0.95 \mathrm{~g} / \mathrm{ml}$ respectively. One hundred grams of the extruded product would supply $45 \%$ of the recommended daily allowance for protein in children aged up to 12 years. The mineral content in $100 \mathrm{~g}$ extrudates was found to be $52 \mathrm{mg}$ calcium, $3.01 \mathrm{mg}$ iron and $1.23 \mathrm{mg}$ zinc. The retention of amino acids in the extruded products was 88\% - 95\% with lysine-a limiting amino acid in cereals having a loss of $9.1 \%$ after extrusion. Extrusion conditions can be optimized to produce ready-to-eat snack products with high expansion ratio, low bulk density and a good nutritional profile to meet the growing consumer needs for nutritious ready-to-eat snack products.
\end{abstract}

\section{Keywords}

Rice, Sorghum, Soybean, Extrusion, Response Surface Methodology, Snacks

\section{Introduction}

There is a growing consumer interest in ready-to-eat snack foods mainly due to their convenience, wide availa-

*Corresponding author.

How to cite this paper: Omwamba, M. and Mahungu, S.M. (2014) Development of a Protein-Rich Ready-to-Eat Extruded Snack from a Composite Blend of Rice, Sorghum and Soybean Flour. Food and Nutrition Sciences, 5, 1309-1317.

http://dx.doi.org/10.4236/fns.2014.514142 
bility, appearance, taste and texture. Population-based studies have shown increased food consumption related to the snacking habit [1]. Extrusion technology has been used in many industries that produce new and unique snack foods due to advances in this technology compared to other traditional methods [2]. Extrusion is a hightemperature short-time process which involves simultaneous thermal and pressure treatment along with mechanical shearing, resulting in changes such as gelatinization of starch, denaturation of protein, and at times complete cooking of the extrudates to obtain ready-to-eat products [3]. Many extruded products are mostly made from cereals such as corn, rice and wheat. These cereals are rich in carbohydrates and fibers but relatively low in protein content, thus they need to enhance the protein component in the extruded products [4]-[7]. Due to consumer demand for healthy extruded snack foods, many industries have increased focus in research and product development to produce products that are nutrient-dense [8].

Rice flour prepared from rice brokens has become an ingredient of interest for many ready-to-eat breakfast cereals and snacks due to its bland taste, attractive white colour, hypoallergenicity and ease of digestion [9]. Rice has relatively low protein content (6 - $8 \mathrm{~g} / 100 \mathrm{~g}$ dry basis), and therefore it needs to enhance the protein component of snack products made from it. Sorghum (Sorghum bicolor (L.) Moenchis) on the other hand is a semi-arid crop grown in most parts of the world and which has been explored in the production of many traditional and novel foods [10]. Dyke and Rooney [11] have reviewed the antioxidant activity in sorghum and millets, and their use as nutraceuticals in foods. Many researchers have used sorghum in flour blends for the production of snacks using extrusion technology [5] [7] [12]. Extrusion processing of sorghum flour improves sorghum protein solubility and functionality [13]-[15]. Soybean is an inexpensive plant source of protein whose protein quality is considered equivalent to animal protein [16]. Addition of soybean can act as a good source of protein in formulated food products besides offering other functional, nutritional and health benefits [17].

Physical characteristics of snacks, such as expansion, hardness and density, are important parameters that affect functional characteristics and acceptability of the final products [5] [7] [18]. The addition of soy protein has been reported to reduce expansion and increase hardness [19] [20] in extruded cereal products. Extrusion cooking should therefore be controlled in order to obtain quality extruded products if blends of cereals and soybean have to be used.

The objective of this study was to investigate the effect of extrusion conditions (barrel temperature, screw speed and feed moisture) on the physical properties (expansion ratio and bulk density) of extruded snack products made from blends of rice, sorghum and soybean flour. Optimum extrusion conditions were established and the nutritional quality of the extruded snack product was prepared using these conditions analyzed.

\section{Materials and Methods}

\subsection{Materials and Chemicals}

Rice and sorghum flour were obtained from a local miller. Defatted soy flour (45\% protein) was from Chemicals \& Solvents (E.A.) Ltd. A mixture of 65\% rice, 20\% sorghum and 15\% defatted soy flour was mixed for 5 min in a ribbon blender ready for extrusion processing. All the reagents used for analysis were of analytical grade.

\subsection{Extrusion Cooking}

A co-rotating twin-screw extruder (DS32-II, Jinan Saixin Food Machinery, Shandong, People's Republic of China) consisting of three independent zones of controlled temperature in the barrel was used to carry out extrusion cooking. The length to diameter ratio of the extruder barrel was 20:1 while the diameter of the screw was $30 \mathrm{~mm}$. The die diameter was $3 \mathrm{~mm}$ and the cutter speed was set at $20 \mathrm{rpm}$. The extruder was fed manually at the rate of $30 \mathrm{~kg} / \mathrm{h}$ through a conical hopper while avoiding accumulation of material. The screw speed, the temperature of the third barrel section (metering section) and the water flow were adjusted to the required levels. After stable conditions were achieved the extrudates were collected into drying pans and dried in an air convection oven at $50^{\circ} \mathrm{C}$ for $30 \mathrm{~min}$ to moisture content of $6.7 \% \pm 0.15 \%$. Dried samples were stored in air tight plastic containers at room temperature until analysis.

\subsection{Experimental Design}

Barrel temperature, screw speed, and feed moisture are the three most important independent factors that affect the properties of extrudates during extrusion. The extrusion conditions were optimized with Box-Behnken design for physical properties. Response surface methodology (RSM) was used to investigate the effect of the in- 
dependent variables on expansion ratio and bulk density. The independent variables and their levels were selected based on information obtained from literature and preliminary experiments. The factors and levels investigated in the study are shown in Table 1. Experimental design, data analysis, and quadratic model building were conducted using the software Design Expert (Version 6.0.5, Stat-Ease Inc., Minneapolis, MN, USA). A Box-Behnken design with three variables was used to determine the response pattern and then establish a model [21] [22]. Five replicates at the center of the design were used to allow for estimation of pure error sum of squares. Experiments were randomized to maximize the effects of unexplained variability in the observed responses due to extraneous factors. The response function $(Y)$ was partitioned into linear, quadratic, and interactive components.

$$
Y=\beta_{0}+\sum_{i=1}^{k} B_{i} X_{1}+\sum_{i=1}^{k} B_{i i} X_{2}+\sum_{i>j}^{k} X_{i} X_{i j}
$$

where $\beta_{0}, B_{i}, B_{i i}$ and $B_{i j}$ are coefficients of intercept, linear, quadratic and interactive effects respectively. $X_{i}$ and $X_{j}$ are levels of the independent variables while $k$ is the number of the tested factors $(k=3)$.

\subsection{Expansion Ratio (ER)}

Expansion ratio (ER) was determined according to the procedure described by Ding et al. [23] which defined ER as the ratio of the diameter of the extrudate to the diameter of the die. The measurement of 10 randomly selected extrudates was done using a vernier caliper and the average obtained. Expansion ratio was calculated as:

$$
\mathrm{ER}=\text { Diameter of extrudate/Diameter of die }
$$

\subsection{Bulk Density (BD)}

The displacement method by Seker [24] was used to measure bulk density (BD). Extrudates were cut into strands about $25 \mathrm{~mm}$ long and $15 \mathrm{~g}$ stands weighed $\left(W_{\text {ext }}\right)$. They were then put in a $100 \mathrm{ml}$ cylinder and yellow millet particles added to fill up the cylinder. The extrudates were taken out and the volume (ml) of the yellow millet particles measured $\left(V_{\mathrm{ym}}\right)$. Bulk density was calculates as:

$$
\mathrm{BD}(\mathrm{g} / \mathrm{ml})=W_{\text {ext }} /\left(100-V_{\text {ym }}\right)
$$

Table 1. Coded and actual values used in the Box Behnken experimental design alongside the responses of expansion ratio and bulk density.

\begin{tabular}{cccccc}
\hline \multirow{2}{*}{ Run } & \multicolumn{3}{c}{ Independent variable levels } & \multicolumn{2}{c}{ Responses $^{\mathbf{a}}$} \\
\cline { 2 - 6 } & Screw speed (rpm) & Barrel temperature $\left({ }^{\circ} \mathbf{C}\right)$ & Feed moisture (\%) & Bulk density (g/ml) & Expansion ratio $^{\text {(g) }}$ \\
\hline 1 & $(0) 400$ & $(0) 130$ & $(0) 12$ & 0.82 & 2.52 \\
2 & $(-1) 350$ & $(-1) 110$ & $(0) 12$ & 0.91 & 2.29 \\
3 & $(-1) 350$ & $(0) 130$ & $(+1) 14$ & 0.85 & 2.35 \\
4 & $(0) 400$ & $(0) 130$ & $(0) 12$ & 0.82 & 2.60 \\
5 & $(0) 400$ & $(-1) 110$ & $(+1) 14$ & 0.85 & 2.34 \\
6 & $(0) 400$ & $(+1) 150$ & $(+1) 14$ & 0.87 & 2.00 \\
7 & $(-1) 350$ & $(+1) 150$ & $(0) 12$ & 0.82 & 2.40 \\
8 & $(0) 400$ & $(0) 130$ & $(-1) 10$ & 0.82 & 2.51 \\
9 & $(+1) 450$ & $(0) 130$ & $(0) 12$ & 0.93 & 2.31 \\
10 & $(+1) 450$ & $(+1) 150$ & $(-1) 10$ & 0.88 & 2.41 \\
11 & $(-1) 350$ & $(0) 130$ & $(-1) 10$ & 0.87 & 2.14 \\
12 & $(0) 400$ & $(+1) 150$ & $(-1) 10$ & 0.89 & 2.05 \\
13 & $(0) 400$ & $(-1) 110$ & $(0) 12$ & 0.95 & 2.47 \\
14 & $(+1) 450$ & $(-1) 110$ & $(0) 12$ & 0.84 & 2.53 \\
15 & $(0) 400$ & $(0) 130$ & $(0) 12$ & 0.83 & 2.50 \\
16 & $(0) 400$ & $(0) 130$ & $(+1) 14$ & 0.84 & 2.56 \\
17 & $(+1) 450$ & $(0) 130$ & & 0.79 & \\
\hline
\end{tabular}

${ }^{\mathrm{a}}$ Values are means of three determinations. 


\subsection{Proximate Analysis}

The extruded products were analyzed for moisture, crude protein $(\mathrm{N} \times 6.25)$, total fat and ash content using AOAC (2010) standard methods. Carbohydrate content was determined by difference $100-(\%$ moisture $+\%$ protein $+\%$ fat $+\%$ ash) while dietary fiber was by AACC [25] standard method.

\subsection{Mineral Analysis}

Selected minerals were determined using the atomic absorption spectrophotometer (AAS) method [26]. 1 - $2 \mathrm{~g}$ of sample was ashed and dissolved in $5 \mathrm{ml}$ of $20 \%$ hydrochloric acid $(\mathrm{HCl})$. Calcium, zinc and iron were determined by a Perkin Elmer Model 603 atomic absorption spectrophotometer. For calcium the final solution contained $1 \%$ lanthanum to overcome interferences.

\subsection{Amino Acid Analysis}

The method of Sotelo et al. [27] was used to determine the amino acid content of the samples. One gram of sample was dissolved in $20 \mathrm{ml}$ of $6 \mathrm{~N}$ HC1. This was then poured into a hydrolysis tube with screw cap and hydrolysed for $22 \mathrm{~h}$ under a nitrogen atmosphere. The acid was evaporated using a rotary evaporator (and residue washed three times with distilled water). The extracted sample was dissolved in $1 \mathrm{ml}$ acetate buffer of $\mathrm{pH}$ 3.1. After dilution to a known volume, the hydrolysate was transferred into a Beckman system (model 6300) high performance amino acid analyzer.

\section{Results}

\subsection{Model Fitting}

The extrudates experimental values of ER and BD using the Box-Behnken design are given in Table 1. Analysis of variance (ANOVA) (Table 2) indicated that the model fitness was significant $(P<0.05)$ while the lack of fit was not significant $(P>0.05)$ for both ER and BD. Coefficient of determination $\left(R^{2}\right)$ is defined as the ratio of the explained variation to the total variation, and is a measurement of the degree of fitness. For the expansion ratio, $R^{2}$ was 0.9813 and CV 1.56 while for bulk density $R^{2}$ was 0.9819 and CV 1.03. By computation, the optimal conditions for the production of an extruded snack with high ER (2.60) and low BD (0.79 g/ml) were found to be; barrel temperature $120^{\circ} \mathrm{C}$, screw speed $444 \mathrm{rpm}$ and feed moisture of $13 \%$.

\subsection{Expansion Ratio (ER)}

The mathematical model representing ER of extrudates as a function of the independent variables within the region under investigation was expressed by the following equation:

$$
\mathrm{ER}=2.53-0.047 X_{1}+0.042 X_{3}-0.088 X_{1} X_{2}-0.11 X_{1} X_{3}+0.078 X_{2} X_{3}-0.23 X_{1}^{2}+0.045 X_{2}^{2}-0.17 X_{3}^{2}
$$

where $X_{1}, X_{2}$, and $X_{3}$ are the coded variables for barrel temperature, screw speed, and feed moisture respectively.

Barrel temperature and feed moisture had significant $(P<0.05)$ effect on the expansion of extrudates. Figure 1 shows the effect of extrusion conditions on the expansion ratio of extrudates. The effect of temperature $(P=$ $0.0177)$ and that of moisture $(P<0.0001)$ significantly $(P<0.05)$ affected ER while that of speed $(P=0.7419)$ was not significant. The interaction effects were all significant. Expansion ratio in the extrudates ranged from 2.0 to 2.6 (Table 1). The ER of extrudates increased with increase in temperature up to about $130^{\circ} \mathrm{C}$ and thereafter there was a decrease with further increase in temperature (Figure 1(a) and Figure 1(b)).

\subsection{Bulk Density (BD)}

Bulk density which indicates the porosity of the snack was significantly $(P<0.05)$ affected by the barrel temperature and moisture content but had no significant $(P=0.7006)$ effect with screw speed. The fitted model for bulk density is given below:

$$
\mathrm{BD}=0.83-0.011 X_{1}-0.35 X_{3}+0.032 X_{1} X_{2}+0.020 X_{1} X_{3}-0.030 X_{2} X_{3}+0.033 X_{1}^{2}+0.00325 X_{2}^{2}-0.031 X_{3}^{2}
$$

where $X_{1}, X_{2}$, and $X_{3}$ are the coded variables for barrel temperature, screw speed, and feed moisture respectively. 
Table 2. Analysis of variance (ANOVA) for the fitted quadratic polynomial model.

\begin{tabular}{ccccccc}
\hline \multirow{2}{*}{ Source } & \multicolumn{3}{c}{ Expansion ratio (ER) } & \multicolumn{3}{c}{ Bulk density (BD) } \\
\cline { 2 - 7 } & Sum of squares & df & Probability $(\boldsymbol{P})>\mathbf{F}$ & Sum of squares & df & Probability $(\boldsymbol{P})>$ F \\
Model & 0.05 & 9 & $<0.0001$ & 0.03 & 9 & $<0.0001$ \\
Residual & 0.009 & 7 & & 0.0005 & 7 & 0.5011 \\
Lack of fit & 0.003 & 3 & 0.6040 & 0.0002 & 3 & 4 \\
Pure error & 0.006 & 4 & & 0.0003 & 4 & 16 \\
Total & 0.51 & 16 & & 0.030 & \\
\hline
\end{tabular}

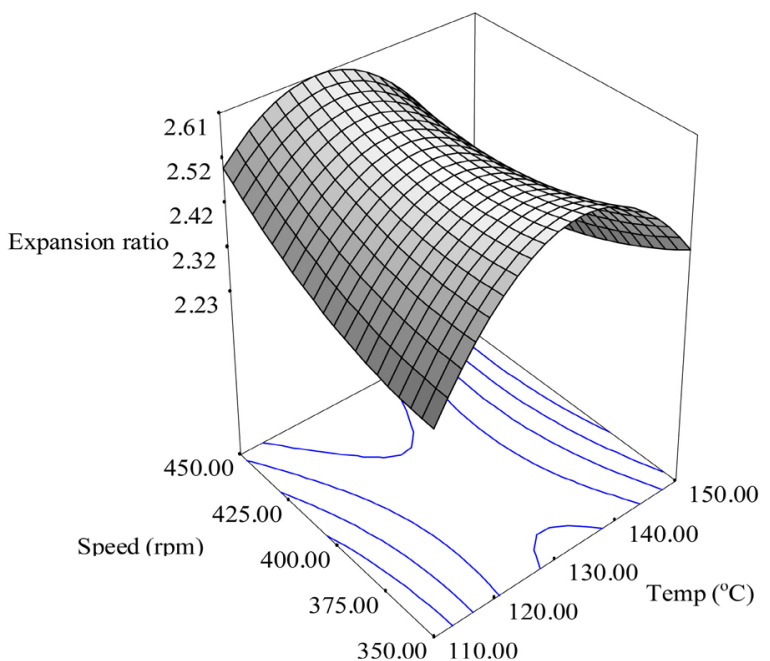

(a)

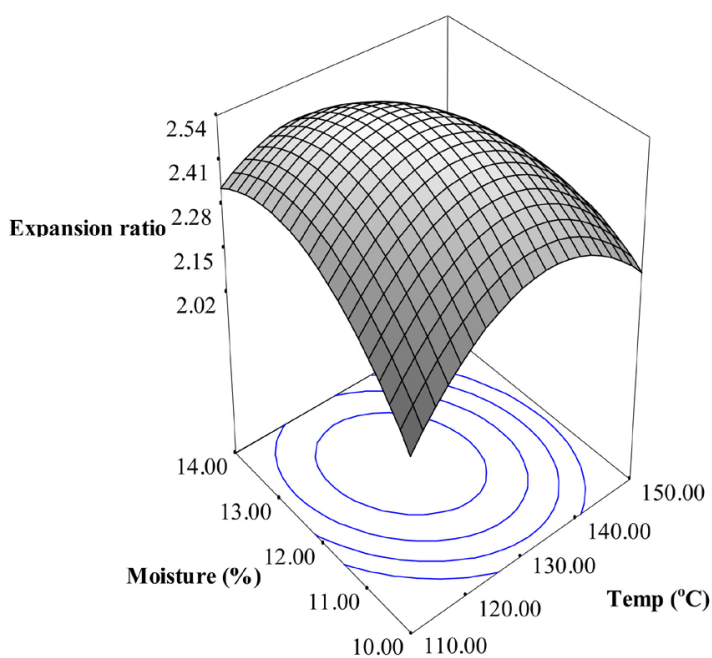

(b)

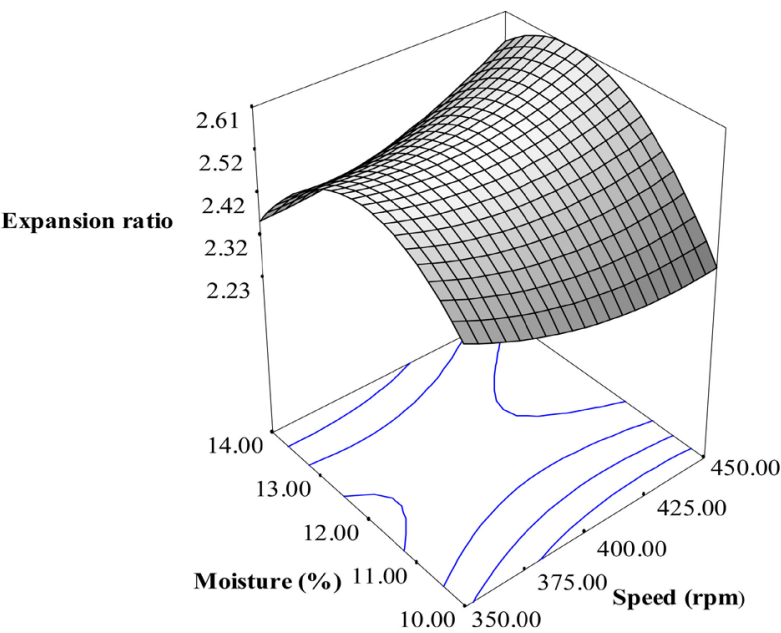

(c)

Figure 1. Response surface plots showing effects of extrusion conditions (barrel temperature, screw speed, and moisture content) on the expansion ratio of extrudates. (a) Moisture content was held constant at $12 \%$; (b) Screw speed was held constant at $400 \mathrm{rpm}$; (c) Temperature was held constant at $130^{\circ} \mathrm{C}$.

Bulk density of the extrudates ranged from 0.79 to $0.95 \mathrm{~g} / \mathrm{ml}$ (Table 1). Figure 2 shows the response surface plot for the effect of extrusion conditions on BD. Feed moisture had the highest significant effect $(P<0.0001)$ on BD. Low feed moisture had a decrease effect on BD (Figure 2(c)) while increase in barrel temperature from $110^{\circ} \mathrm{C}$ to $140^{\circ} \mathrm{C}$ led to a decrease in the BD of extrudates (Figure 2(a)). Figure 2(b) shows that the interaction of feed moisture and barrel temperature led to a decrease in the bulk density.

A significant $(P<0.05)$ negative correlation $(r=-0.76)$ was found between expansion ratio and bulk density. 


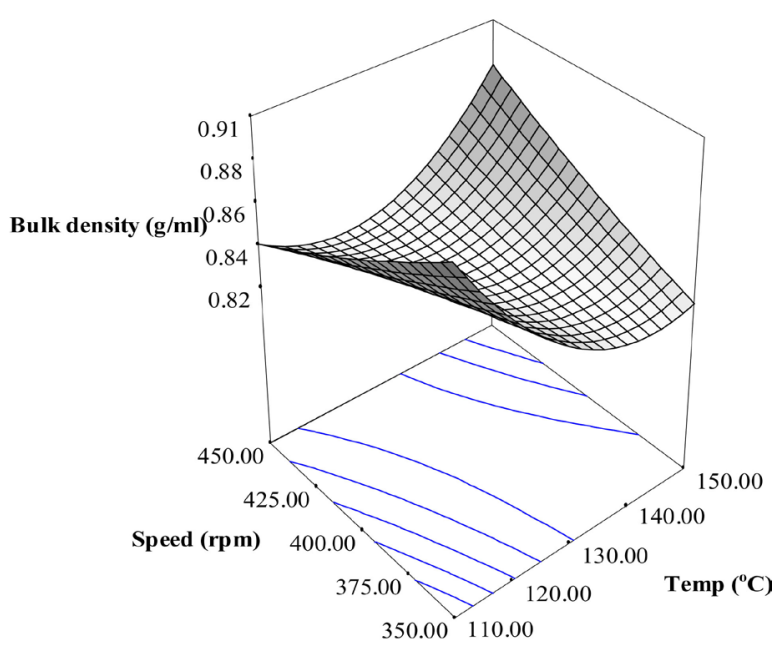

(a)

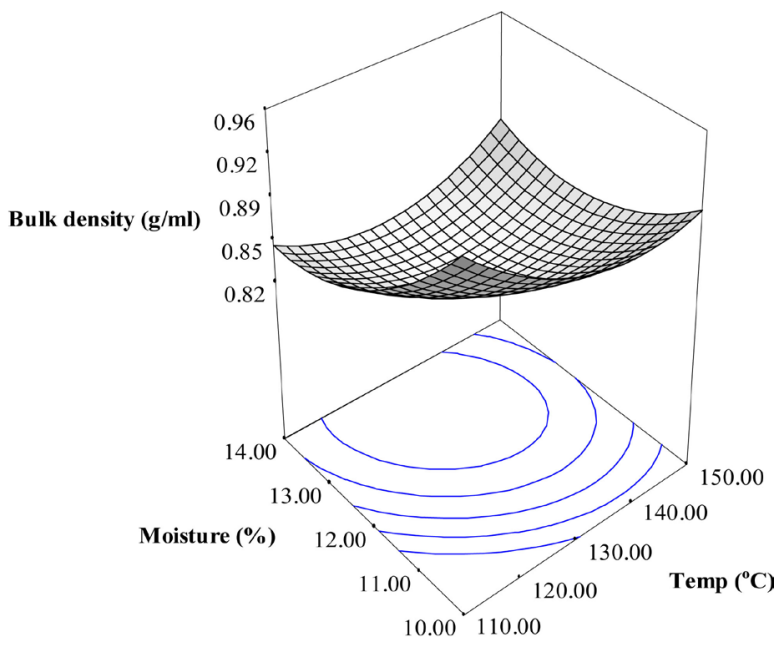

(b)

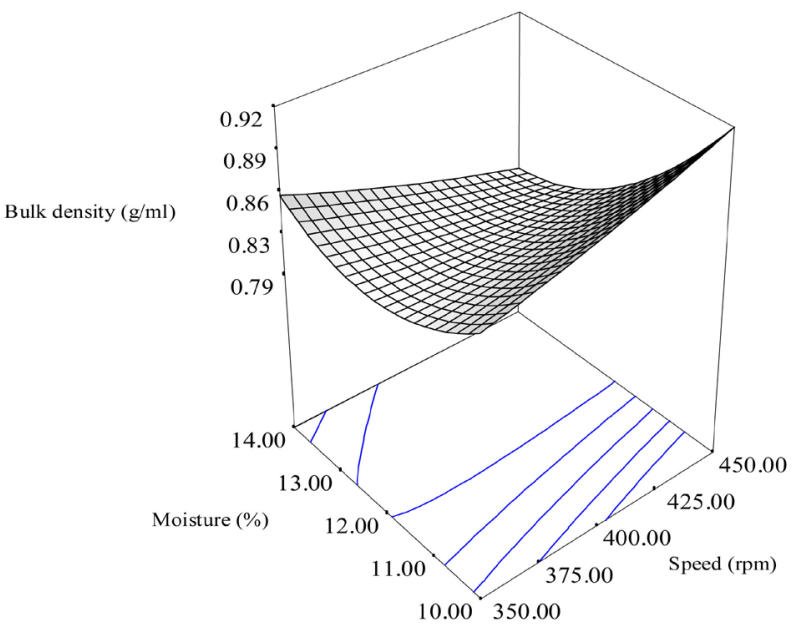

(c)

Figure 2. Response surface plots showing effects of extrusion conditions (barrel temperature, screw speed, and moisture content) on the bulk density of extrudates. (a) Moisture content was held constant at $12 \%$; (b) Screw speed was held constant at $400 \mathrm{rpm}$; (c) Temperature was held constant at $130^{\circ} \mathrm{C}$.

\subsection{Proximate Analysis}

The extruded snack product prepared using optimized conditions was analyzed for proximate composition. The moisture content was found to be $6.72 \% \pm 0.15 \%$, protein $15.31 \% \pm 0.12 \%$, fat $1.89 \% \pm 0.09 \%$, ash $3.01 \% \pm$ $0.11 \%$, carbohydrates $73.07 \% \pm 0.08 \%$ and dietary fiber of $5.20 \% \pm 0.011 \%$. Selected minerals (calcium, iron and zinc) were also determined. The content was $52 \pm 0.21 \mathrm{mg}$ calcium, $3.01 \pm 0.11 \mathrm{mg}$ iron and $1.23 \pm 0.92 \mathrm{mg}$ zinc per 100 g product.

\subsection{Amino Acid Composition}

Table 3 shows the amino acid composition of the blend before extrusion and the extruded product. In this study the retention of amino acids in the extruded products was high (88\% - 95\%) with lysine a limiting amino acid in cereals having a loss of $9.1 \%$ after extrusion. The extruded snack produced from rice, sorghum and defatted soy flour blend had lysine content of $1.19 \pm 0.09 \mathrm{~g} / 100 \mathrm{~g}$ sample (Table 3).

\section{Discussion}

Generally, the validity of the model is judged by the lack of fit to check its adequacy. Exploration and optimiza- 
tion of a fitted response surface may produce poor or misleading results, unless the model exhibits a good fit. The results indicate that the model equation was adequate for predicting the responses under any combination of independent variables. The model had a high coefficient of determination $\left(R^{2}\right)$ and low coefficient of variation (CV). The model fits well with the actual data when $R^{2}$ approaches unity. The study therefore indicates that there was a good precision and reliability for the experiment.

Expansion ratio describes the degree of puffing a sample undergoes as it exits from the extruder. A higher expansion ratio is desirable in the production of extruded snacks. Feed moisture has been found to be the most significant factor affecting expansion ratio [23]. Increase in feed moisture from $10 \%$ to $13 \%$ led to an increase in ER which then decreased when feed moisture was increased further to 14\% (Figure 1(b) and Figure 1(c)). Hagenimana et al. [28] reported a decrease in ER with increasing feed moisture from $16 \%-22 \%$ when rice flour was extruded in a twin screw. They found ER of extrudates ranging from 1.61 to 3.94. Suitable moisture which is dependent on extrusion conditions and feed composition is important for expansion of an extruded product. Too much moisture reduces shear strength and energy input to the material resulting in decreased moisture evaporation at the die exit and therefore low ER [6]. In our study the use of soybean and sorghum flour increased the protein level and decreased the starch level in the blend which may have impended full starch gelatinization. Devi et al. [7] in development of a protein-rich sorghum expanded snack reported an increase in expansion ratio with increase in corn flour and a decrease with the addition of protein source. This indicates that the structure of extruded products depends on starch gelatinization. Increasing the ratio of starch to protein leads to formation of a continuous starch matrix that enables water vapour to expand because starch melt viscosity is lower than protein melt viscosity [7] [14] [29]. The decrease in ER with a further increase in temperature beyond $130^{\circ} \mathrm{C}$ was probably due to the greater fragmentation of starch as reported by Hagenimana et al. [28].

The non-significant $(P=0.7006)$ effect of speed screw on bulk density in this study is in agreement with Suksomboon et al. [30]. Hagenimana et al. [28] reported a range of 0.1248 to $0.6937 \mathrm{~g} / \mathrm{cm}^{3}$ in expanded products made from rice flour. Values in our study were higher due to high protein levels in the blend and the properties of protein in sorghum flour. The Kafirin storage proteins which are the majority of sorghum proteins are generally not thought of as functional proteins and might impede full starch gelatinization [31]. An inverse relationship has been reported between feed moisture content and the density of extrudates [23] [32]. Increase in barrel temperature would have led to superheating of water which led to bubble formation and also a decrease in melt viscosity which increased expansion and decreased density. Ding et al. [23] reported the same results with rice-based expanded snacks while Thymi et al. [18] reported a reduction in bulk density of expanded wheat snacks with high barrel temperature of up to $140^{\circ} \mathrm{C}$. The higher the expansion ratio, the lower the bulk density,

Table 3. Amino acid in dry blend and extruded products.

\begin{tabular}{|c|c|c|}
\hline \multirow{2}{*}{ Amino acid } & \multicolumn{2}{|c|}{ AA content (g/100g sample) ${ }^{\mathrm{a}}$} \\
\hline & Dry blend & Extruded product \\
\hline Aspartic acid & $2.54 \pm 0.04$ & $2.38 \pm 0.13$ \\
\hline Threonine & $1.17 \pm 0.12$ & $1.03 \pm 0.11$ \\
\hline Serine & $1.08 \pm 0.09$ & $0.97 \pm 0.02$ \\
\hline Glutamic acid & $3.81 \pm 0.02$ & $3.53 \pm 0.09$ \\
\hline Glycine & $1.04 \pm 0.13$ & $0.95 \pm 0.07$ \\
\hline Alanine & $1.40 \pm 0.05$ & $1.27 \pm 0.11$ \\
\hline Cysteine & $0.27 \pm 0.05$ & $0.25 \pm 0.05$ \\
\hline Valine & $1.09 \pm 0.06$ & $0.99 \pm 0.02$ \\
\hline Methionine & $0.34 \pm 0.07$ & $0.31 \pm 0.04$ \\
\hline Isoleucine & $0.99 \pm 0.03$ & $0.94 \pm 0.05$ \\
\hline Leucine & $1.76 \pm 0.08$ & $1.65 \pm 0.07$ \\
\hline Thyrosine & $0.78 \pm 0.02$ & $0.75 \pm 0.12$ \\
\hline Phenylalanine & $1.32 \pm 0.05$ & $1.19 \pm 0.11$ \\
\hline Histadine & $0.52 \pm 0.07$ & $0.46 \pm 0.08$ \\
\hline Lysine & $1.31 \pm 0.09$ & $1.19 \pm 0.09$ \\
\hline Arginine & $1.73 \pm 0.07$ & $1.53 \pm 0.04$ \\
\hline Tryptophan & $0.31 \pm 0.10$ & $0.28 \pm 0.09$ \\
\hline
\end{tabular}

${ }^{\mathrm{a}}$ Values are means \pm standard deviation of 3determinations on dry weight basis. 
as the two are negatively correlated [6] [7] [33].

One hundred grams (100 g) serving of the extruded product will supply $45 \%$ of the recommended daily allowance (RDA) of protein (RDA of $34 \mathrm{~g}$ /day) for children up to 12 years old. The extruded product represents a good source of protein and dietary fiber. The micronutrient profile indicates that the extruded product developed with high expansion and low bulk density was also rich in minerals. Snacking with this kind of product will help improve the nutrient requirements giving the increase in snacking trends [1].

A high loss in lysine implies a reduction in the nutritional value of the extruded cereal products. Iwe et al. [33] reported available lysine range of $68 \%-100 \%$ in extrudates of a mixture of defatted soy flour and sweet potato flour. Loss in amino acid may be due to Maillard reaction that occurs between free amino groups of protein and carbonyl groups of reducing sugars. Lysine loss in extrusion is largely influenced by process temperature, feed moisture, and the presence of other sugars. Low-moisture conditions and high temperature promote Maillard reaction which according to Singh et al. [3] causes significant loss in lysine (5\% - 40\%) and other sulphur containing amino acids in conventional steam-based extrusion depending on processing conditions and ingredient composition. The daily lysine requirement for humans is $1.0-1.5 \mathrm{~g}$ [16] which means the extruded product in this study can supply lysine within the daily requirement.

The inclusion of a soy protein source in cereal flour increases the protein content and improves the amino acid balance in the extruded products which ultimately improve the nutritional value of the products. A blend of rice, sorghum and defatted soy flour can be used to prepare ready-to-eat snacks with improved nutritional profile and textural properties. These results will assist the food industry whose focus is research and product development towards production of nutritious extruded snack products.

\section{References}

[1] Nicklas, T.A., Yang, S.J., Baranowski, T., Zakeri, I. and Berenson, G. (2003) Eating Patterns and Obesity in Children: The Bogalusa Heart Study. American Journal of Preventive Medicine, 25, 9-16. http://dx.doi.org/10.1016/S0749-3797(03)00098-9

[2] Riaz, M.N. (2000) Extruders in Food Applications. Technomic Publishing, Lancaster.

[3] Singh, S., Gamlath, S. and Wakeling, L. (2007) Nutritional Aspects of Food Extrusion: A Review. International Journal of Food Science and Technology, 42, 916-929. http://dx.doi.org/10.1111/j.1365-2621.2006.01309.x

[4] Mahungu, S.M., Diaz-Mercado, S., Li, J., Schwenk, M., Singletary, K. and Faller, J. (1999) Stability of Isoflavones during Extrusion Processing of Corn/Soy Mixture. Journal of Agriculture and Food Chemistry, 47, 279-284. http://dx.doi.org/10.1021/jf980441q

[5] Seth, D. and Rajamanickam, G. (2012) Development of Extruded Snacks Using Soy, Sorghum, Millet and Rice BlendA Response Surface Methodology Approach. International Journal of Food Science and Technology, 47, $1526-1531$. http://dx.doi.org/10.1111/j.1365-2621.2012.03001.x

[6] Yu, L., Ramaswamy, H.S. and Boye, J. (2012) Twin-Screw Extrusion of Corn Flour and Soy Protein Isolate (SPI) Blends: A Response Surface Analysis. Food Bioprocess Technology, 5, 485-497. http://dx.doi.org/10.1007/s11947-009-0294-8

[7] Devi, N.L., Shobha, S., Tang, X., Shaur, S.A., Dogan, H. and Alavi, S. (2013) Development of Protein-Rich Sorghum-Based Expanded Snacks Using Extrusion Technology. International Journal of Food Properties, 16, 263-276. http://dx.doi.org/10.1080/10942912.2011.551865

[8] Brennan, C., Brennan, M., Derbyshire, E. and Tiwari, B.K. (2011) Effects of Extrusion on the Polyphenols, Vitamins and Antioxidant Activity of Foods. Trends in Food Science and Technology, 22, 570-575. http://dx.doi.org/10.1016/j.tifs.2011.05.007

[9] Kadan, R.S., Bryant, R.J. and Pepperman, A.B. (2003) Functional Properties of Extruded Rice Flours. Journal of Food Science, 68, 1669-1672. http://dx.doi.org/10.1111/j.1365-2621.2003.tb12311.x

[10] Taylor, J., Schober, T.J. and Bean, S.R. (2006) Novel Food and Non-Food Uses for Sorghum and Millets. Journal of Cereal Science, 44, 252-271. http://dx.doi.org/10.1016/j.jcs.2006.06.009

[11] Dykes, L. and Rooney, L.W. (2006) Sorghum and Millets Phenols and Antioxidants. Journal of Cereal Science, 44, 236-251. http://dx.doi.org/10.1016/j.jcs.2006.06.007

[12] Jadhav, M.V. and Annapure, U.S. (2013) Effect of Extrusion Process Parameters and Particle Size of Sorghum Flour on Expanded Snacks Prepared Using Different Varieties of Sorghum (Sorghum bicolour L.). Journal of Agriculture Science and Technology, B3, 71-85.

[13] Hamaker, B.R., Mertz, E.T. and Axtell, J.D. (1994) Effect of Extrusion on Sorghum Kafirin Solubility. Cereal Chemi- 
stry, 71, 515-517.

[14] Pelembe, L.A.M., Erasmus, C. and Taylor, J.R.N. (2002) Development of a Protein-Rich Composite Sorghum-Cowpea Instant Porridge by Extrusion Cooking Process. LWT, Food Science and Technology, 35, 120-127. http://dx.doi.org/10.1006/fstl.2001.0812

[15] Llopart, E.E., Drago, S.R., De Greef, D.M., Torres, R.S. and Gonzáles, R.J. (2014) Effects of Extrusion Conditions on Physical and Nutritional Properties of Extruded Whole Grain Red Sorghum (Sorghum spp). International Journal of Food Science and Nutrition, 65, 34-41. http://dx.doi.org/10.3109/09637486.2013.836737

[16] FAO (1991) Protein Quality Evaluation. Report of the Joint FAO/WHO Expert Consultation; FAO Food and Nutrition Paper No. 51, FAO, Bethesda, 44-51.

[17] Friedman, M. and Brandon, D.L. (2001) Nutritional and Health Benefits of Soy Proteins. Journal of Agriculture and Food Chemistry, 49, 1069-1086.

[18] Thymi, S., Krokida, M.K., Pappa, A. and Maroulis, Z.B. (2005) Structural Properties of Extruded Corn Starch. Journal of Food Engineering, 68, 519-526. http://dx.doi.org/10.1016/j.jfoodeng.2004.07.002

[19] Li, S., Zhang, H.Q., Jin, Z.T. and Hsieh, F. (2005) Textural Modification of Soya Bean/Corn Extrudates as Affected by Moisture Content, Screw Speed and Soya Bean Concentration. International Journal of Food Science and Technology, 40, 731-741. http://dx.doi.org/10.1111/j.1365-2621.2005.00993.x

[20] De Mesa, N.J.E., Alavi, S., Singh, N., Shi, Y.C., Dogana, H. and Sang, Y. (2009) Soy Protein-Fortified Expanded Extrudates: Baseline Study Using Normal Corn Starch. Journal of Food Engineering, 90, 262-270. http://dx.doi.org/10.1016/j.jfoodeng.2008.06.032

[21] Box, G.E.P. and Behnken, D.W. (1960) Some New Three Level Designs for the Study of Quantitative Variables. Technometrics, 2, 455-475. http://dx.doi.org/10.1080/00401706.1960.10489912

[22] Omwamba, M. and Hu, Q. (2010) Antioxidant Activity in Barley (Hordeum vulgare L.) Grains Roasted in a Microwave Oven under Conditions Optimized Using Response Surface Methodology. Journal of Food Science, 75, C66C72.

[23] Ding, Q.B., Ainsworth, P., Tucker, G. and Marson, H. (2005) The Effect of Extrusion Conditions on the Physicochemical Properties and Sensory Characteristics of Rice-Based Expanded Snacks. Journal of Food Engineering, 66, 283289. http://dx.doi.org/10.1016/j.jfoodeng.2004.03.019

[24] Seker, M. (2005) Selected Properties of Native or Modified Maize Starch/Soy Protein Mixtures Extruded at Varying Screw Speed. Journal of the Science of Food and Agriculture, 85, 1161-1165. http://dx.doi.org/10.1002/jsfa.2086

[25] AACC (2005) Approved Methods. American Association of Cereal Chemists, St. Paul.

[26] AOAC (2010) Official Methods of Analysis. 18th Edition, Revision 3, Association of Official Analytical Chemists, Washington DC.

[27] Sotelo, A., Hernandez, M., Montalvo, I. and Sousa, V. (1994) Amino Acid Content and Protein Biological Evaluation of 12 Mexican Varieties of Rice. Cereal Chemistry, 71, 605-609.

[28] Hagenimana, A., Ding, X. and Fang, T. (2006) Evaluation of Rice Flour Modified by Extrusion Cooking. Journal of Cereal Science, 43, 38-46. http://dx.doi.org/10.1016/j.jcs.2005.09.003

[29] Zasypkin, D.V., Yuryev, V.P., Alexeyev, V.V. and Tolstoguzov, V.B. (1992) Mechanical Properties of the Products Obtained by the Thermoplastic Extrusion of Potato Starch-Soybean Protein Mixtures. Carbohydrate Polymer, 18, 119124. http://dx.doi.org/10.1016/0144-8617(92)90133-B

[30] Suksomboon, A., Limroongreungrat, K., Sangnark, A., Thititumjariya, K. and Noomhorm, A. (2011) Effect of Extrusion Conditions on the Physicochemical Properties of a Snack Made from Purple Rice (Hom Nil) and Soybean Flour Blend. International Journal of Food Science and Technology, 46, 201-208. http://dx.doi.org/10.1111/j.1365-2621.2010.02471.x

[31] Hamaker, B.R. and Bugusu, B.A. (2003) Overview: Sorghum Proteins and Food Quality. Proceedings of AfriproWorkshop on the Proteins of Sorghum and Millets: Enhancing Nutritional and Functional Properties for Africa, Pretoria, 2-4 April 2003. http://www.afripro.org.uk/papers/Paper08Hamaker.pdf

[32] Chaiyakul, S., Jangchud, K., Jangchud, A., Wuttijumnong, P. and Winger, R. (2009) Effect of Extrusion Conditions on Physical and Chemical Properties of High Protein Glutinous Rice-Based Snack. LWT, Food Science and Technology, 42, 781-787.

[33] Iwe, M.O., Van Zuilichem, D.J. Ngoddy, P.O., Lammers, W. and Stolp, W. (2004) Effect of Extrusion Cooking of Soy- Sweet Potato Mixtures on Available Lysine Content and Browning Index of Extrudates. Journal of Food Engineering, 62, 143-150. http://dx.doi.org/10.1016/S0260-8774(03)00212-7 
Scientific Research Publishing (SCIRP) is one of the largest Open Access journal publishers. It is currently publishing more than 200 open access, online, peer-reviewed journals covering a wide range of academic disciplines. SCIRP serves the worldwide academic communities and contributes to the progress and application of science with its publication.

Other selected journals from SCIRP are listed as below. Submit your manuscript to us via either submit@scirp.org or Online Submission Portal.
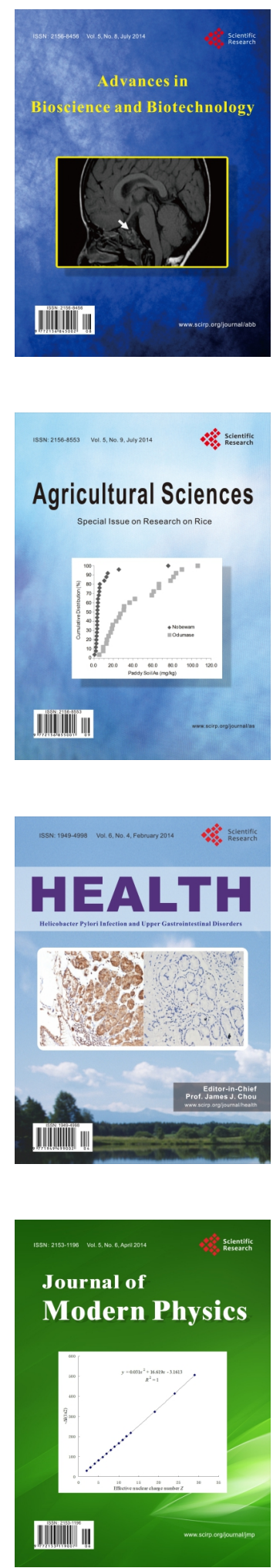
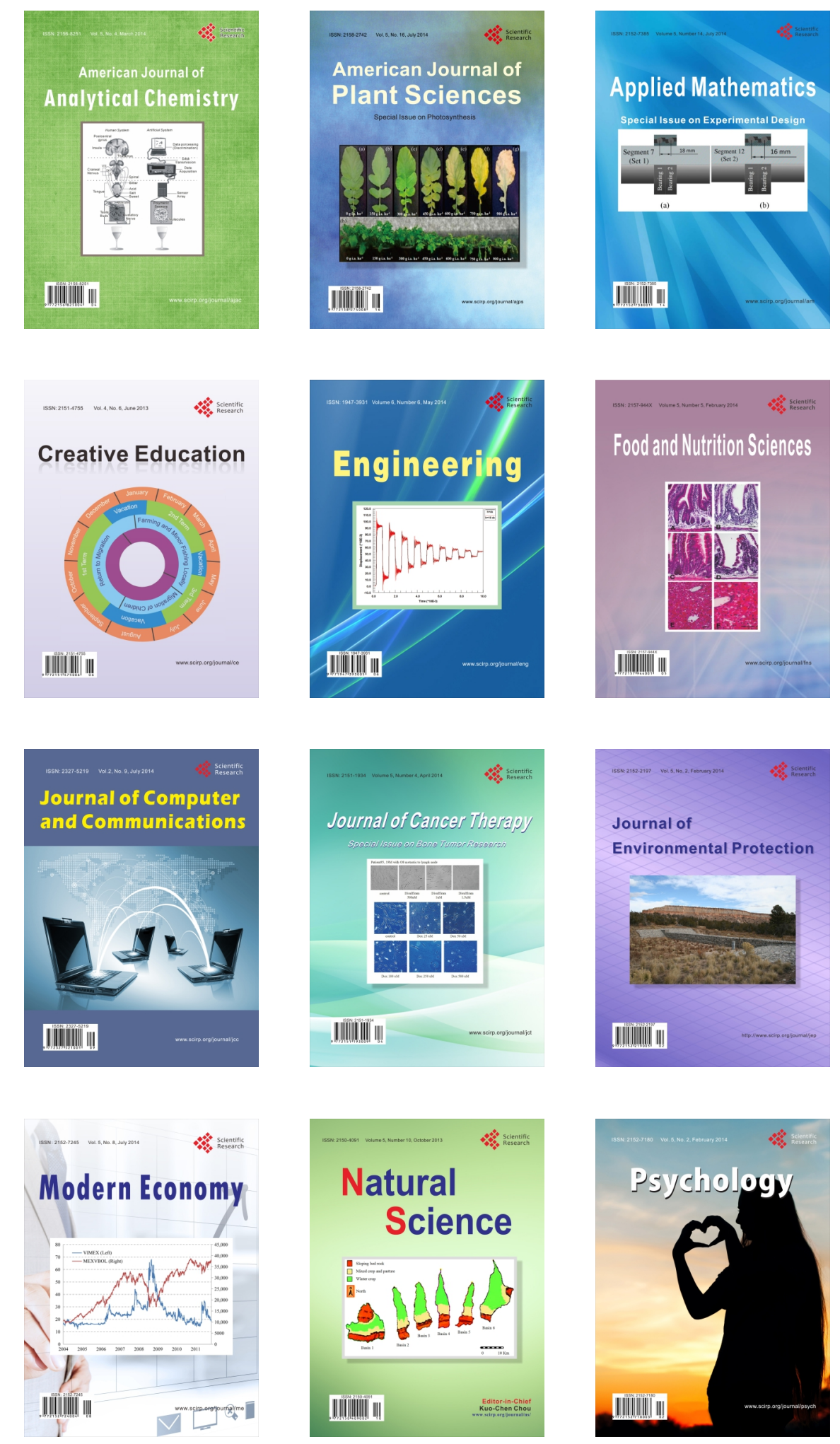